\title{
İlkokul Yöneticilerinin Kültürel Liderlik Davranışları ile Öğretmenlerin Örgütsel İmajı Arasındaki İlişkinin İncelenmesi
}

\author{
Mevlüt UYGUR \\ Milli Eğitim Bakanlığ1 \\ muygur1978@gmail.com \\ ORCID ID: 0000-0002-3880-5731
}

\begin{tabular}{lrr} 
Araştırma Makalesi & DOI: $10.31592 /$ aeusbed.683343 \\
\hline Geliş Tarihi: 01.02 .2020 & Revize Tarihi: 16.11 .2020 & Kabul Tarihi: 10.02 .2021
\end{tabular}

\section{Atıf Bilgisi}

Uygur, M. (2021). İlkokul yöneticilerinin kültürel liderlik davranışları ile öğretmenlerin örgütsel imajı arasındaki ilişkinin incelenmesi. Ahi Evran Üniversitesi Sosyal Bilimler Enstitüsü Dergisi, 7(1), 15-31.

\section{ÖZ}

$\mathrm{Bu}$ araştırmanın amacı öğretmenlerin algılarına göre ilkokul yöneticilerinin kültürel liderlik davranışları ile öğretmenlerin örgütsel imajı arasındaki ilişkiyi belirlemektir. Araştırmada ilişkisel tarama yöntemi kullanılmıştır. Araştırmanın evreni 2018-2019 öğretim yılında Konya ilinde devlet okullarında çalışan öğretmenleri kapsamaktadır. Okulların ve öğretmenlerin sayısını tespit etmek için Konya İl Milli Eğitim Müdürlügünün verilerinden yararlanılmıştır. Araştırmanın örneklemi basit tesadüfi örnekleme yöntemiyle 18 ilkokuldan seçilen 380 öğretmendir. Verilerinin toplanmasında, "Kültürel Liderlik Ölçeği” ile "Örgütsel İmaj Ölçeği" kullanılmıştır. Elde edilen verilerin analizinde SPSS paket programından yararlanılmıştır. Verilerin çözümlenmesinde aritmetik ortalama, standart sapma, Mann Whitney U-testi, Kruskal Wallis H- testi ve Spearman rho korelasyon analizlerinden faydalanılmıştır. Araştırmadan elde edilen sonuçlara göre, öğretmenlerin ilkokul yöneticilerinin kültürel liderlik davranışlarına ilişkin algılarının genel ortalamasının "Katılıyorum" düzeyinde olduğu belirlenmiştir. Öğretmenlerin örgütsel imaj algılarının genel ortalaması ise "Oldukça Katılıyorum" düzeyinde olduğu bulunmuştur. Ayrıca öğretmenlerin algılarına göre, ilkokul yöneticilerinin kültürel liderlik davranışlarıyla öğretmenlerin örgütsel imajı arasında orta düzeyde pozitif ve anlamlı ilişkinin olduğu ortaya çıkmıştır.

Anahtar Kelimeler: Kültürel liderlik davranışları, imaj, örgütsel imaj.

\section{Examination the Relationship Between Primary School Principals 'Cultural Leadership Behavior and Teachers' Organizational Image}

\begin{abstract}
The aim of this research is to determine the relationship between the cultural leadership behaviors of primary school principals and the organizational image of teachers according to the perceptions of teachers. Relational screening method was used in the research. The universe of research covers teachers working in public schools in Konya province in the 2018-2019 academic year. In order to determine the number of schools and teachers, the data of Konya Provincial Directorate of National Education was used. The sample of the research is 380 teachers selected from 18 primary schools by simple random sampling method. "Cultural Leadership Scale" and "Organizational Image Scale" were used to collect data. SPSS package program was used to analyze the data obtained. Arithmetic mean, standard deviation, Mann Whitney U-test, Kruskal Wallis H-test and Spearman rho correlation analysis were used to analyze the data. According to the results from the study, the overall average of teachers ' perceptions of the cultural leadership behaviour of primary school principals was found to be at the "Agree" level. The overall average of teachers ' perceptions of organizational image was found to be at the level of "quite agree". In addition, according to the perceptions of teachers, it has been revealed that there is a moderate positive and meaningful relationship between the cultural leadership behavior of primary school principals and the organizational image of teachers.
\end{abstract}

Keywords: Cultural leadership behaviors, image, organizational image.

\section{Giriş}

Sanayi, bilim ve teknolojik alandaki baş döndürücü değişimler ve gelişmeler bütün alanları olumlu ve olumsuz şekilde etkilemiştir. Bu durum neticesinde örgütler ortaya çıkmıştır. Örgütler sayesinde bu değişim ve gelişmelere uyum kolaylaşmıştır. Bu kadar önemli bir fonksiyona sahip olan örgüt hakkında çeşitli tanımlar yapılmıştır. Bursalıoğlu (2005) örgütü üyeleri tarafından kurulan bir koalisyon olarak tanımlarken, Gürsel'e (2003) göre ise örgüt iş bölümü yaparak, bir otorite hiyerarşisi içinde ortak bir amacı gerçekleştirmek için bir araya gelmiş insanların faaliyetlerinin koordinasyonu şeklinde ifade etmektedir. Örgütler karmaşık ve dinamiktir. Belirli amaçları gerçekleştirmek için biçimsel yapılara sahiptir fakat kendi özel ihtiyaçları, ilgileri ve sık sık örgütsel beklentilerle çelişen 
inançları olan insanlardan oluşmaktadır (Hoy ve Miskel, 2015). Örgütlerin başlıca görevlerinden biri amaçlarına en kısa sürede ve en verimli bir biçimde varabilmektir. Etkililik seviyesi yüksek olan örgütlerin çıktıları ve hizmet hacimlerinin yüksek ve daha kaliteli olmasından amaçlarına daha çabuk ve etkin ulaşabileceklerdir (Ak, 2017). Etkili örgütler, güçlü ve ayırt edici bir ortak kültüre sahiptir ve yönetsel liderliğin temel işlevi örgütün kültürünü oluşturmaktır (Hoy ve Miskel, 2015).

Örgüt kültürü eğitim bilimleri alanında önemle durulmakta, bu konuda çok sayıda araştırma yapılmaktadır (Buluç, 2013). Örgüt kültürü bir toplumun dışsal çevredeki yaşamsal sorunlarını ve içsel bütünleşme problemlerini çözerken belirli bir sürede öğrendikleridir (Schein, 1990). Örgüt kültürü örgüt üyelerince paylaşılan inanç ve varsayımlar örüntüsüdür. Örgüt kültürünün bazı önemli özellikleri gözlenen davranış düzenlemeleri, normlar, baskın değerler, ilkeler, kurallar ve duygulardır (Lunenburg ve Ornstein, 2013). Williams, Dabson ve Walters (1993) örgüt kültürünün özelliklerini beş gruba ayırmıştır. Bunlar:

1. Kültürün öğrenilebildiği,

2. Kültürün kısmen bilinçsizce oluştuğu,

3. Kültürün bir örgütün hem girdisi hem de çıktısı olduğu,

4. Kültürün yaygın olarak kabul gören değer ve tutumlardan oluştuğu,

5. Örgüt kültürünün hetorojen olduğudur (Akt. Terzi, 2000).

Okul kültürü ise okul topluluğunu biraraya getiren düşünce, değer, varsayım, inanış ve davranışlardan meydana gelmektedir (Çelikten, 2003). "Okul kültürü okula has değer, inanç ve normların birleşiminden oluşmaktadır. Bütün örgütlerde olduğu gibi bütün okullarında kendine has bir kültürü bulunmaktadır" (Özdemir, 2012, s. 605). Güçlü, etkin ve güvene dayalı kültürlere sahip okullarda öğrencilerin başarıları yüksektir (Hoy ve Miskel, 2015). Okul müdürleri kültürü zaman içinde şekillendirirken olumlu bir okul iklimi oluşturmak için çalışırlar (Çelikten, 2003). Olumlu okul kültürüne sahip okullarda informal ilişkiler daha yüksektir. Yöneticiler, öğretmenler, öğrenciler ve diğer personel birbirine saygı duyarlar. Yardımlaşma ön plandadır. Yöneticiler her konuda öğretmen ve öğrencileri destekler. Bu sayede okulun hedeflerinin gerçekleşmesi kolaylaşacaktır. Bu bağlamda olumlu bir okul kültürünü oluşturacak olanda okullardaki yöneticilerinin kültürel liderlik davranışlarıdır.

Örgütsel kültür kavramı 1980'li yıllardan itibaren popüler bir kavram olarak kullanılmaya başlanmıştır. Sadece örgüt ve yönetim kuramı değil diğer sosyal bilimlerde ki bilim adamlarının ilgi odağı haline gelmiştir (Şişman, 1995). Bu bağlamda örgütsel kültür kavramı liderlik araştırmalarını özellikle de kültürel liderliği etkilemiştir. Kültürel liderlik, okul etkililiğine yol açan temel değerlerin ve normların değerlendirilmesine, oluşturulmasına ve aracılık edilmesine katılan okul liderliğinin alternatif bir perspektifi şeklinde tanımlanabilir (Lane, 1992). Kültürel liderin davranışı, örgüt kültürünü yaşatmaktır. Örgütlerdeki kültürel değerlerinin meydana getirilmesi için çalışan, değerleri bilen, izah eden ve çalışanların bu değerlerle bütünleşmesini sağlayan kültürel liderdir. Bundan dolayı kültürel liderler, işgörenlerin örgütün düşünce, değer, norm, tarih, kahraman, lisan ve merasimlerini öğrenmesini, içselleştirilmesini ve kullanmasını sağlamaya çalışır (Maya, 2017). Kültürel liderlik önemli bir sembolik karaktere sahiptir. Kültürü aktarma ve yerleştirme çabalarında, liderler, üyelerin çevrelerini anlamasına yardımcı olan dil, hikayeler, jestler ve prosedürler gibi çeşitli sembolik formları kullanırlar (Dandridge, 1983; Tierney, 1989; Akt. Baker ve Associates, 1992).

Okuldaki yöneticiler kültürel lider olarak, okulunun en iyisi olmasını sağlayabilmek amacıyla zamanını ve enerjisini geleneklerin, grup normlarının, değerlerin ve güncel alışkanlıkların oluşturulmasına ve okul ortamındaki paylaşılmakta olan değerlerin artırılmasını sağlamalıdır. Çünkü okul kültüründeki değerler gelenek haline getirilirse bürokratik kurallar azalacak ve örgütteki işgörenler kendi davranışlarını düzenleyebilecektir. Kültürel liderlikte temel olarak etkili bir örgüt kültürün geliştirilmesi çabaları bulunmaktadır (Gedikoğlu, Şahin ve Büyükelbaşı, 2004). Kültürel liderlikte, eğitim örgütlerindeki okul müdürlerinin sahip oldukları temel değerlerin, amaçların, ideallerin, ilkelerin ve inançlarının aracılığıyla öğrencilerin karakter eğitimine katkı vermektedir (Maya, 2017). Kültürel liderliği başarılı bir şekilde üstlenebilen müdürler, okul başarısının bağlı 
olduğu temel içerik ve süreçlere yakından uyum sağlayacaktır (Lane, 1992). Kültürel liderlik yaklaşımında yöneticiler ile çalışanlar arasında yakın ilişki kurulması düşüncesi olduğundan çalışanların üzerinde olumlu etkilerinin olduğu söylenebilir. Örgütteki çalışanların iş tatminlerini ve duygusal bağlılıklarını yükselterek çalışanların performanslarını artırmaktadır. Bunun sayesinde örgütlerin verimliliğinde artış görülecektir. Sonuçta hem örgütler hem de çalışanlar hedeflerine ulaşacaklardır (Köksal, 2011). Kültürel liderliğin iki temel bileşeni bulunmaktadır. Birincisi mevcut olan kültürün korunmasıdır. İkinci bileşeni ise yeni bir kültürün oluşturulmasıdır. Kültürel liderler, kendilerini yalnızca okul kültürüyle sınırlandırmazlar. Okuldaki yönetici; okul kültürünün çevreye taşınmasını ve toplumsal kültüründe okula taşınması için uğraşırken, dengenin kurulması, kültürel taşıyıcılık ve seçicilik rolleri yapmaya çalışmaktadır. Okullardaki yöneticilerin kültürel liderlik rollerini başarılı bir şekilde yapabilmeleri için öncelik olarak kendilerinin örgüt kültürlerini iyi anlaması gerekir. Ayrıca örgüt kültürünü personellerine ve çevrelerine tanıtması ve kabullenilmesi gerekmektedir (Geylani, 2013).

Araştırmacıların üzerinde durduğu konulardan biride örgütsel imaj kavramıdır. İmaj sözcüğü, farklı insanlar için farklı anlamlar ifade eder. Bazıları imaj kavramına olumlu yaklaşmakta, bazıları da imaj kavramının suni ve hakikatten uzak, yapay özellikler veya davranış biçimlerini oluşturduğu düşüncesine sahiptir. Gerek olumlu gerek olumsuz açıdan konuya bakılsada, imaj kavramı bundan sonra yaşamımızın bir parçası olmuştur (Dincer, 1998). Dowling'e (1986) göre imajın tanımı, insanın bir obje hakkındaki görüş, düşünce, duygu ve izlenimlerinin net sonucudur (Akt. Frandsen, 2017). İmaj, bireylerin bir nesne, örgüt ya da farklı bir birey hakkındaki görüşleri olarak ifade edilebilir (Okay, 2000). Genel olarak imaj, herhangi bir bireyin, örgüt veya durum ile ilgili tüm görüşlerinin toplamı şeklinde yorumlanabilir (Peltekoğlu, 1997). Bolat (2006) imajın özelliklerini:

- İmaj, değişik kanallardan elde edilmiş bilgiler ve verilerin değerlendirilmesi sonucunda oluşmuştur.

- İmaj, yavaş yavaş oluşmakta ve zamanla değişmektedir.

- İmajla oluşan hükümler, nesnel ya da öznel bilgilere dayanmaktadır.

- İmaj kişi ve kurumlar aracılığıyla bilinçli oluşabildiği gibi bilinçsizce de oluşabilir, şeklinde açıklamıştır.

Örgütsel imaj, yirminci yüzyılda dünya genelinde ki tüm sektör, meslek ve bölgelerde ki yöneticilerin başlica konusu haline gelmiştir (Vigoda Gadot, Vinarski-Peretz ve Ben-Zion, 2003). Bu nedenle örgütsel imajın bütün alanları etkilediği söylenebilir. Örgütsel imajla ilgili alanyazında çok sayıda tanım yapılmıştır. Bu tanımlardan bazıları şunlardır; Dutton ve Dukerich'e (1991) göre örgütsel imaj, örgütün tüm paydaşlarının örgüt hakkındaki düşünceleridir. Livens'e (2017) göre örgütsel imaj insanların örgüt hakkındaki bilgi ve inançlarıdır. Kurşun'a (2011) göre ise örgütsel imaj çevredeki ve örgütteki bireylerin örgütü nasıl gördüklerini anlatır. Örgütle ilgili görüşleri de belirten örgütsel imaj bireylerin kararlarını ve düşüncelerini doğrudan etki etmektedir. Bu itibarla birbirleriyle yarışma durumundaki örgütler, insanların kendilerinin yanında olmalarını sağlamak için, çevrelerine karşı olumlu bir imaj oluşturmak zorundadır. Bu olumlu imaja sahip örgütler diğer rakiplerinden bir adım önde olurlar. Başarıları ve pazardaki kar oranları daha yüksektir. Vigoda Gadot vd., (2003) örgütsel imajın özelliklerini:

- Örgütün istikrarı, pazardaki ve toplumdaki itibarı;

- Müşteriler tarafindan görülen örgütün çıktı ve sonuçlarının kalitesi;

- Örgütün diğer rakip örgütlerle karşılaştırıldığında üretici veya hizmet sağlayıcı olarak konumu;

• Örgüt paydaşlarının veya çalışanların örgütün eylemlerine dahil olmak için genel istekliliği, şeklinde siralamıştır.

Bir kuruluşun izleyicileri ve çalışanlarının algıladığı örgütsel imaj, kuruluşların etkin performansını doğrudan etkilemektedir (Pérez ve Torres, 2017). Bu bağlamda örgütün sürekliliği ve başarısı için güçlü ve olumlu bir örgütsel imajın olması gerekir. Güçlü bir örgütsel imaj örgütlere hissi 
yönden değer ilave ederek, örgütlerin fark edilmelerini ve güvenilir olmalarını sağlayarak, rakiplerinin önüne geçmesine imkân sağlamaktadır (Erdoğan, Develioğlu, Gönüllüoğlu ve Özkan, 2006). Tüm örgütler başarılı olmak için olumlu ve devamlı bir örgütsel imaj elde etmeyi amaçlamaktadır. Olumlu ve devamlı bir örgütsel imajına sahip olan örgütler yarış durumunda üstünlük elde ederler (Akbulut, 2015). Bu sayede örgütlerin hedeflerine ulaşmaları kolaylaşacaktır. Olumlu bir okul imajı, okuldaki çalışanların motivasyonunun artmasına, performanslarını daha etkili ve daha verimli kullanmasına, iş birliği kurmasına, iş doyumuna ve iş bağlılığının yükselmesine neden olmaktadır (Duman, 2012). Bu bakımdan okuldaki etkileri değerlendirildiğinde güçlü ve olumlu okul imajı eğitim örgütleri için çok önemlidir. Okulda güçlü ve olumlu imajı oluşturacak olan da okul yöneticileridir. Pawlas'a (1999) göre okuldaki imajın oluşmasında en etkili faktörün okulda görev yapan yöneticilerin olduğunu ifade etmektedir (Akt. Bahçeci, 2009). Bunun gerçekleşebilmesi için okul yöneticilerinin liderlik davranışlarını en iyi şekilde sergilemesi gerekir. Bu davranışlardan biriside kültürel liderliktir.

Okullarda etkili ve olumlu bir örgütsel imajı meydana getirmek için güçlü ve işlevsel bir okul kültürü oluşturmak gerekir. Bu okul kültürünü oluşturacak olan da okuldaki yöneticilerin kültürel liderlik davranışlarıdır. İlgili alanyazın incelemesi sonucunda ilkokul yöneticilerinin kültürel liderlik davranışlarıyla öğretmenlerin örgütsel imajı arasındaki ilişkiye dair herhangi bir araştırmaya rastlanılmadığından bu çalışmayla literatüre katkıda bulunmayı hedeflemektedir. Ayrıca okulun varlığını uzun süre koruması, hedeflerini gerçekleştirmesi ve verimliliği açısından bu araştırma önem taşımaktadır. Bu bağlamda bu araştırmanın amacı öğretmenlerin algılarına göre ilkokul yöneticilerinin kültürel liderlik davranışları ile öğretmenlerin örgütsel imajı arasındaki ilişkiyi belirlemektir. $\mathrm{Bu}$ amacın gerçekleşmesi için aşağıdaki alt amaçlara cevap aranacaktır.

1. Öğretmenlerin algılarına göre, ilkokul yöneticilerinin kültürel liderlik davranışları ne düzeydedir?

2. Öğretmenlerin ilkokul yöneticilerinin kültürel liderlik davranışları düzeylerine ilişkin algıları cinsiyetlerine, mesleki kıdemlerine, branşlarına ve öğrenim durumlarına göre anlamlı fark var midır?

3. Öğretmenlerin ilkokullarındaki örgütsel imajı ne düzeydedir?

4. Öğretmenlerin ilkokullarındaki örgütsel imaj düzeylerine ilişkin algıları cinsiyetlerine, mesleki kıdemlerine, branşlarına ve öğrenim durumlarına göre anlamlı fark var mıdır?

5. Öğretmenlerin algılarına göre ilkokul yöneticilerinin kültürel liderlik davranışları ile öğretmenlerin örgütsel imajı arasında anlamlı bir ilişki var mıdır?

\section{Yöntem}

$\mathrm{Bu}$ bölümde araştırmanın modeli, evren ve örneklemi, veri toplama araçları, verilerin analizi ve araştırma etiğine ilişkin ayrıntılı bilgilere yer verilmiştir.

\section{Araştırma Modeli}

Çalışmada nicel araştırma yöntemi kullanılmıştır. Kültürel liderlikle örgütsel imaj ilişkisi araştırırken ilişkisel tarama modelinden faydalanılmıştır. Bu modelde, iki veya daha çok değişken arasında değişim varlığını ve derecesi tespit edilmeye çalışılır (Karasar, 2008). Bu bağlamda, ilkokul öğretmenlerinin algılarına göre ilkokul yöneticilerinin kültürel liderlik davranışlarıyla öğretmenlerin örgütsel imajı arasındaki ilişki incelenmiştir.

\section{Evren ve Örneklem}

Araştırmanın evreni 2018-2019 öğretim yılı Konya ilinde devlet okullarındaki çalışan öğretmenleri kapsamaktadır. Araştırmanın örneklemi basit tesadüfi örnekleme yöntemiyle 18 ilkokuldan seçilen 380 öğretmendir. Araştırmaya katılan öğretmenlerin 233'ü (\%61.3) kadın, 147'si (\%38.7) erkektir. Mesleki kıdemleri incelendiğinde, 87'si (\%22.9) 1-10 yı1, 82'si (\%21.6) 11-20 yıl ve 211'i (\%55.5) 21 yıl ve üstü olduğu bulunmuştur. Öğretmenlerden 317'si (\%83.4) sinıf öğretmeni, 
63'ü (\%16.6) branş öğretmenidir. Araştırmaya katılanların 349’u (\%91.8) lisans, 31’i (\%8.2) lisansüstü mezunudur.

\section{Veri Toplama Araçları}

$\mathrm{Bu}$ çalışmada kullanılan ölçek üç kısımdan oluşmuştur. Birinci kısımda ilkokul öğretmenlerinin kişisel özelliklerini öğrenmek için kişisel bilgi formu oluşturulmuştur. İkinci kısımda Yıldırım'ın (2001) "Kültürel Liderlik Ölçeğì" kullanılmıştır. Bu ölçekte; okul yöneticilerin kültürel liderlik rollerine ilişkin öğretmen görüşlerini belirlemeyi amaçlayan 21 soru vardır. Üçüncü kısımda Şahin'in (2014) Türkçe’ye uyarladığg “Örgütsel İmaj Ölçeği” kullanılmıştır. Bu ölçekte öğretmenlerin örgütsel imajını belirlemek için 9 soru vardır. Çalışmada kullanılan ölçekler için araştırmacılardan gerekli izinler alınmıştır. Ayrıca bu çalışma için Konya Milli Eğitim Müdürlüğünden 28.05.2019 tarih ve 83688308-605.99-E.10437852 sayı ile gerekli araştırma izni alınmıştır.

\section{Kişisel Bilgi Formu}

Öğretmenlerin demografik özellikleri için hazırlanan bu formda "cinsiyetleri”, "mesleki kıdemleri”, "branşları”, "öğrenim durumları" değişkenleri bulunmaktadır.

\section{Kültürel Liderlik Ölçeği}

Yıldırım (2001) "Kültürel Liderlik Ölçeği’nde" okul yöneticilerinin kültürel liderlik rollerini ölçmek amacıyla 21 madde bulunan bir ölçek geliştirmiştir. Ölçek tek boyuttan oluşmaktadır. Geçerliği ve güvenirliği yapılan bu ölçekte iç tutarlılık katsayısı Cronbach Alpha .88 bulunmuştur. Bu çalışmada araştırmacı tarafından kültürel liderlik ölçeğinin geçerliği için açımlayıcı faktör analizi yapılmıştır. Güvenirliği için iç tutarlılık katsayısı hesaplanmıştır. Araştırma verilerinin, faktör analizine uygunluğu için Kaiser-Meyer-Olkin (KMO) katsayısı ve Barlett Sphericity testi hesaplanmıştır. KMO katsayısının .60'dan yüksek çıkması ve Barlett Sphericity testi sonucunun anlamlı olması araştırma verilerinin faktör analizi için kullanılabilir (Büyüköztürk, 2008). Araştırma sonucunda KMO katsayıs1 .97 bulunmuştur. Barlett Sphericity testi sonucu ise $(9598.51 ; \mathrm{p}<0.01)$ anlamlı çıkmıştır. Bu sonuçlara göre faktör analizi yapılmıştır. Faktör analizinin sonucuna göre 21 maddeden oluşan tek faktörlü bir yapısı olan ölçeğin faktör yükleri .73 ile .91 arasında değiştiği bulunmuştur. Bu faktörün ölçeğe ilişkin açıkladıkları varyans oranı \%73.22'dir. Ayrıca iç tutarlık katsayısı Cronbach Alpha .98 bulunmuştur. Sonuçlara göre ölçek geçerli ve güvenilirdir.

\section{Örgütsel İmaj Ölçeği}

Örgütsel imaj ölçeğini Gioia ve Thomas (1996) geliştirmiştir (Akt. Şahin, 2014). Bu ölçek ilk defa üniversitedeki yöneticilerinin imajlarını ölçmek için kullanılmıştır. Örgütsel imaj ölçeğini Şahin (2014) ortaöğretimde çalışan öğretmenlerin örgütsel imajlarını ölçmek için Türkçe'ye uyarlanmıştır. Ölçeğin dilsel eşdeğerliğii, geçerliği ve güvenirliği yapılan ölçek tek boyutludur ve dokuz madde bulunur. İç tutarlılık katsayısı Cronbach Alpha .93 bulunmuştur. Bu çalışmada araştırmacı tarafindan örgütsel imaj ölçeğinin geçerliği için açımlayıcı faktör analizi yapılmıştır. Güvenirliği için iç tutarlılık katsayısı hesaplanmıştır. Araştırma verilerinin, faktör analizine uygunluğu için KMO katsayısı ve Barlett testi hesaplanmıştır. Araştırma sonucunda KMO katsayısı .93 bulunmuştur. Barlett Sphericity testi sonucu ise $(3370.82 ; \mathrm{p}<0.01)$ anlamlı çıkmıştır. Bu sonuçlara göre faktör analizi yapılmıştır. Faktör analizinin sonucuna göre 9 maddeden oluşan tek faktörlü bir yapısı olan ölçeğin faktör yükleri .74 ile .92 arasında değiştiği bulunmuştur. Bu faktörün ölçeğe ilişkin açıkladıkları varyans oranı \%76.30'dur. Ayrıca iç tutarlık katsayısı Cronbach Alpha .96 bulunmuştur. Sonuçlara göre ölçek geçerli ve güvenilirdir.

\section{Verilerin Toplanması ve Analizi}

Ölçekler aracılığıyla toplanan verilerin analizinde SPSS paket programından faydalanılmıştır. Veriler analiz edilmeden önce verilerin normal dağılıp dağılmadığını bulmak için çarpıklık ve basıklık 
katsayıları ile Kolmogorov-Smirnov testine bakılmıştır. Sonuçta verilerin normal dağılmadığ1 görülmüştür. $\mathrm{Bu}$ yüzden araştırmada verilerin analizinde non-parametrik testler kullanılmıştır. Araştırmada aritmetik ortalama, standart sapma ve non-parametrik testler olan iki örneklem grubu için Mann-Whitney U-testi, üç ve daha fazla örneklem grubunun analizinde ise Kruskal Wallis H-testi ve Kültürel liderlik ile örgütsel imaj arasındaki ilişki olup olmadığını bulmak için Spearman rho korelasyon analizlerinden yararlanılmıştır. Anlamlılık düzeyi, $\mathrm{p}<0.01$ ve $\mathrm{p}<0.05$ olarak değerlendirilmiştir.

\section{Araştırma Etiği}

Bu çalışmada "Yükseköğretim Kurumları Bilimsel Araştırma ve Yayın Etiği Yönergesi" kapsamında bütün kurallara uyulmuştur. Ayrıca bu çalışma için Necmettin Erbakan Üniversitesi Sosyal ve Beşeri Bilimler Araştırma ve Yayın Etiği Kurulunun 30.3.2020 tarih ve 2020/08 sayılı etik kurul onayı alınmıştır.

\section{Bulgular}

\section{İlkokul Yöneticilerinin Kültürel Liderlik Davranışlarına İlişkin Bulgular}

Kültürel Liderlik Ölçeği ile ilkokullarda çalışan öğretmenlerden toplanan verilerin istatistiksel olarak çözümlenmesi sonucu elde edilen bulgular aşağıda verilmiştir. İlk olarak öğretmenlerin algılarının genel ortalaması alınarak, ilkokul yöneticilerinin kültürel liderlik davranışlarının ne düzeyde olduğu Tablo 1'de gösterilmiştir.

Tablo 1

Öğretmenlerin Algllarına Göre İlkokul Yöneticilerinin Kültürel Liderlik Davranışlarının Düzeyi

\begin{tabular}{lcccc}
\hline & $\mathbf{N}$ & $\overline{\mathbf{x}}$ & $\mathbf{S S}$ & Katılım Düzeyi \\
\hline Kültürel Liderlik & 380 & 4.19 & .85 & Katılıyorum \\
\hline
\end{tabular}

Tablo 1'e göre araştırmaya katılan öğretmenlerin algılarına göre ilkokul yöneticilerinin kültürel liderlik davranışlarının düzeyinin "Katılıyorum" ( $\bar{x}=4.19)$ olduğu belirlenmiştir. Bu bulguya göre öğretmenler yöneticilerinin kültürel liderlik davranışlarını başarılı bulmuşlardır. Öğretmenlerin ilkokul yöneticilerinin kültürel liderlik davranışları düzeylerine ilişkin algıları cinsiyete göre farklılığı Mann-Whitney U- Testi analizi Tablo 2'de verilmiştir.

Tablo 2

Öğretmenlerin Algılarına Göre İlkokul Yöneticilerinin Kültürel Liderlik Davranışları Düzeylerininin Cinsiyetlerine Göre Farklılı̆̆ $\mathrm{Mann}$-Whitney U-Testi Sonucu

\begin{tabular}{lcccccc}
\hline & Cinsiyet & n & Sira Ortalaması & Sıra Toplamı & U & p \\
\hline Kültürel & Kadın & 233 & 188.42 & 43901.00 & 16640.000 & .641 \\
Liderlik & Erkek & 147 & 193.80 & 28489.00 & & \\
& & & & & & \\
\hline
\end{tabular}

p>.05

Tablo 2'ye göre öğretmenlerin ilkokul yöneticilerinin kültürel liderlik davranışları düzeylerine ilişkin algıları cinsiyetlerine göre anlamlı olarak fark olmadığı tespit edilmiştir ( $U=16640.000, p>.05$ ). Öğretmenlerin ilkokul yöneticilerinin kültürel liderlik davranışları düzeylerine ilişkin algıları mesleki kıdeme göre farklılı̆̆ Kruskal Wallis H- Testi analizi Tablo 3'de gösterilmiştir. 
Tablo 3

Öğretmenlerin Algılarına Göre İlkokul Yöneticilerinin Kültürel Liderlik Davranışları Düzeylerininin Mesleki Kıdemlerine Göre Farklılı̆̆ı Kruskal Wallis H-Testi Analizi Sonucu

\begin{tabular}{lcrcccc}
\hline & Mesleki Kıdem & n & Sira Ortalaması & sd & $x^{2}$ & p \\
\hline \multirow{2}{*}{ Kültürel } & & & & & & \\
Liderlik & $11-10$ yıl & 87 & 209.60 & 2 & 3.691 & .158 \\
& 21 yıl ve üstü & 82 & 190.16 & & & \\
& 211 & 182.76 & & & \\
\hline
\end{tabular}

$\mathrm{p}>.05$

Tablo 3 incelendiğinde öğretmenlerin ilkokul yöneticilerinin kültürel liderlik davranışları düzeylerine ilişkin algıları mesleki kıdemlerine göre anlamlı fark olmadığı bulunmuştur, $x^{2}(\mathrm{sd}=2$, $\mathrm{n}=380)=3.691, \mathrm{p}>.05$. Öğretmenlerin ilkokul yöneticilerinin kültürel liderlik davranışları düzeylerine ilişkin algıları branşa göre farklılığı Mann-Whitney U- Testi analizi Tablo 4’te verilmiştir.

Tablo 4

Öğretmenlerin Algllarına Göre İlkokul Yöneticilerinin Kültürel Liderlik Davranışları Düzeylerininin Branșlarına Göre Farklıllı̆̆ Mann-Whitney U-Testi Sonucu

\begin{tabular}{lcccccc}
\hline & Branş & n & Sıra Ortalaması & Sıra Toplamı & U & p \\
\hline Kültürel & Sınıf Öğretmeni & 317 & 188.09 & 59626.00 & 9223.000 & .337 \\
Liderlik & Branş Öğretmeni & 63 & 202.60 & 12764.00 & & \\
& & & & & & \\
\hline
\end{tabular}

p>.05

Tablo 4'e göre öğretmenlerin ilkokul yöneticilerinin kültürel liderlik davranışları düzeylerine ilişkin algıları branşlarına göre anlamlı olarak fark olmadığı belirlenmiştir (U=9223.000, p>.05). Öğretmenlerin ilkokul yöneticilerinin kültürel liderlik davranışları düzeylerine ilişkin algıları öğrenim durumlarına göre farklılığı Mann-Whitney U- Testi analizi Tablo 5’te gösterilmiştir.

Tablo 5

Öğretmenlerin Algılarına Göre İlkokul Yöneticilerinin Kültürel Liderlik Davranışları Düzeylerininin Öğrenim Durumlarına Göre Farklılı̆̆ Mann-Whitney U-Testi Sonucu

\begin{tabular}{llrcccc}
\hline \multicolumn{2}{c}{ Öğrenim Durumları } & n & Sıra Ortalaması & Sira Toplamı & U & p \\
\hline \multirow{2}{*}{$\begin{array}{l}\text { Kültürel } \\
\text { Liderlik }\end{array}$} & Lisans & 349 & 189.08 & 65987.50 & 4912.500 & .396 \\
& Lisansüstü & 31 & 206.53 & 6402.50 & &
\end{tabular}

$\mathrm{p}>.05$

Tablo 5’te görüldüğü gibi öğretmenlerin ilkokul yöneticilerinin kültürel liderlik davranışları düzeylerine ilişkin algıları öğrenim durumlarına göre anlamlı olarak fark olmadığı tespit edilmiştir $(\mathrm{U}=4912.500, \mathrm{p}>.05)$. Buna göre lisans mezunu öğretmenler ile lisansüstü mezunu öğretmenlerin algilarının benzer olduğu söylenebilir.

\section{Öğretmenlerin İlkokullarındaki Örgütsel İmajlarına İlişkin Bulgular}

Örgütsel İmaj Ölçeği ile ilkokullarda çalışan öğretmenlerden toplanan verilerin istatistiksel olarak çözümlenmesi sonucu elde edilen bulgular aşağıda verilmiştir. Öğretmenlerin algılarının genel ortalaması alınarak "Araştırmaya katılan öğretmenlerin ilkokullarındaki örgütsel imajına ilişkin algı düzeyleri” Tablo 6'da gösterilmiştir. 
Tablo 6

Illkokul Öğretmenlerinin Örgütsel İmaj Algı Düzeyleri

\begin{tabular}{ccccc}
\hline & $\mathbf{N}$ & $\overline{\mathbf{x}}$ & $\mathbf{S S}$ & Katılım düzeyi \\
\hline Örgütsel İmaj & 380 & 4.02 & .86 & $\begin{array}{c}\text { Oldukça } \\
\text { Katıllyorum }\end{array}$ \\
\hline
\end{tabular}

Tablo 6' da görüldüğü gibi öğretmenlerin ilkokullarındaki örgütsel imajına ilişkin alg1 düzeyleri "Oldukça Katılıyorum" ( $\overline{\mathrm{x}}=4.02)$ olduğu belirlenmiştir. $\mathrm{Bu}$ bulguya göre ilkokul öğretmenlerinin örgütsel imaj algıları yüksektir. Öğretmenlerin ilkokullarındaki örgütsel imaj düzeylerine ilişkin algıları arasında cinsiyete göre farklılı̆g 1 Mann-Whitney U- Testi analizi Tablo 7'de gösterilmiştir.

Tablo 7

Öğretmenlerin İlkokullarındaki Örgütsel İmaj Düzeylerine İlişkin Algllarının Cinsiyetlerine Göre Farklılı̆̆ Mann-Whitney U-Testi Sonucu

\begin{tabular}{lcccccc}
\hline & Cinsiyet & n & Sura Ortalaması & Sıra Toplamı & U & p \\
\hline $\begin{array}{l}\text { Örgütsel } \\
\text { İmaj }\end{array}$ & Kadın & 233 & 190.40 & 44362.50 & 17101.500 & .982 \\
& Erkek & 147 & 190.66 & 28027.50 & & \\
& & & & & &
\end{tabular}

p>.05

Tablo 7'ye göre öğretmenlerin ilkokullarındaki örgütsel imaj düzeylerine ilişkin algıları cinsiyetlerine göre anlamlı olarak fark olmadığı bulunmuştur ( $U=17101.500, p>.05)$. Öğretmenlerin ilkokullarındaki örgütsel imaj düzeylerine ilişkin algıları mesleki kıdeme göre farklılığı Kruskal Wallis H- Testi analizi Tablo 8'de gösterilmiştir.

Tablo 8

Öğretmenlerin İlkokullarındaki Örgütsel İmaj Düzeylerine İlişkin Algılarının Mesleki Kıdemlerine Göre Farklılı̆̆ Kruskal Wallis H-Testi Analizi Sonucu

\begin{tabular}{lcccccc}
\hline & Mesleki Kıdem & $\mathbf{n}$ & Sira Ortalaması & sd & $x^{2}$ & $\mathbf{p}$ \\
\hline & & & & & & \\
Örgütsel & $1-10$ yıl & 87 & 207.02 & 2 & 3.468 & .177 \\
İmaj & $11-20$ y1l & 82 & 195.30 & & & \\
& 21 y1l ve üstü & 211 & 181.82 & & &
\end{tabular}

$\mathrm{p}>.05$

Tablo 8'e göre öğretmenlerin ilkokullarındaki örgütsel imaj düzeylerine ilişkin algıları mesleki kıdemlerine göre anlamlı fark olmadığ $\breve{b}_{1}$ bulunmuştur, $x^{2}(\mathrm{sd}=2, \mathrm{n}=380)=3.468, \mathrm{p}>.05$. Öğretmenlerin ilkokullarındaki örgütsel imaj düzeylerine ilişkin algıları branşa göre farklılığı Mann-Whitney U- Testi analizi Tablo 9'da gösterilmiştir.

Tablo 9

Öğretmenlerin İlkokullarındaki Örgütsel İmaj Düzeylerine İlişkin Algılarının Branşlarına Göre Farklılı̆̆ Mann-Whitney U-Testi Sonucu

\begin{tabular}{llccccc}
\hline & Branş & n & Sıra Ortalaması & Sıra Toplamı & U & p \\
\hline Örgütsel & Sınıf Öğretmeni & 317 & 187.28 & 59367.50 & 8964.500 & .198 \\
İmaj & Branş Öğretmeni & 63 & 206.71 & 13022.50 & & \\
& & & & & & \\
\hline
\end{tabular}

p>.05 
Tablo 9'a göre öğretmenlerin ilkokullarındaki örgütsel imaj düzeylerine ilişkin algıları branşlarına göre anlamlı olarak fark olmadığı belirlenmiştir ( $U=8964.500$, p>.05). Öğretmenlerin ilkokullarındaki örgütsel imaj düzeylerine ilişkin algıları öğrenim durumlarına göre farklılığı MannWhitney U Testi analizi Tablo 10'da sunulmuştur.

Tablo 10

Öğretmenlerin İlkokullarındaki Örgütsel İmaj Düzeylerine İlişkin Algllarının Öğrenim Durumlarına Göre Farklılı̆̆ Mann-Whitney U Testi Sonucu

\begin{tabular}{lcccccc}
\hline & Öğrenim Durumları & n & Sıra Ortalaması & Sıra Toplamı & U & p \\
\hline Örgütsel & Lisans & 349 & 191.99 & 67005.00 & 4889.000 & .373 \\
İmaj & Lisansüstü & 31 & 173.71 & 5385.00 & &
\end{tabular}

$\mathrm{p}>.05$

Tablo 10'da görüldüğü gibi öğretmenlerin ilkokullarındaki örgütsel imaj düzeylerine ilişkin algıları arasında ögrenim durumlarına göre göre anlamlı olarak fark olmadığı bulunmuştur $(\mathrm{U}=4889.000, \mathrm{p}>.05)$. Buna göre lisans mezunu öğretmenler ile lisansüstü mezunu öğretmenlerin algılarının benzer olduğu söylenebilir.

\section{Kültürel Liderlik ile Örgütsel İmaj Arasındaki İlişkiye Yönelik Bulgular}

Öğretmenlerinin algılarına göre, ilkokul yöneticilerinin kültürel liderlik davranışları ile öğretmenlerin örgütsel imajı arasındaki ilişki Tablo 11'de sunulmuştur.

Tablo 11

Kültürel Liderlik ile Örgütsel İmaj Arasındaki İlişkiye İlişkin Spearman Korelasyonu Sonucu

\begin{tabular}{lcc}
\hline & $\begin{array}{c}\text { Külttürel } \\
\text { Liderlik }\end{array}$ & $\begin{array}{c}\text { Örgütsel } \\
\text { İmaj }\end{array}$ \\
\hline Kültürel Liderlik & 1 & $.552^{* *}$ \\
& & 1 \\
Örgütsel İmaj & $.552^{* *}$ & 1
\end{tabular}

Tablo 11'de görüldüğü gibi ilkokul öğretmenlerinin algılarına göre ilkokul yöneticilerinin kültürel liderlik davranışlarıyla öğretmenlerin ilkokullarına yönelik örgütsel imajı arasında orta düzeyde pozitif yönlü anlamlı bir ilişkinin olduğu bulunmuştur $(\mathrm{r}=.552, \mathrm{p} .<.01)$. Elde edilen bulguya göre ilkokul yöneticilerinin kültürel liderlik davranışları artıkça öğretmenlerin ilkokullarına yönelik örgütsel imaj algıları da olumlu yönde artı̧̧ olacağı söylenebilir.

\section{Sonuç, Tartışma ve Öneriler}

Araştırmanın birinci alt amacının sonucuna göre öğretmenlere göre ilkokul yöneticilerinin kültürel liderlik davranışlarının düzeyinin "Katılıyorum" olduğu belirlenmiştir. İlkokul yöneticilerinin kültürel liderlik davranışları yükseğe yakın çıkmıştır. Bu sonuca göre ilkokul yöneticileri kültürel liderlik davranışlarını başarıyla sergilemektedirler. Araştırmanın bulgularıyla, (Ay, 2014; Çek, 2011; Değirmenci, 2006; Derin, 2003; Hiçyılmaz, 2013; Uygur ve Yıldırım, 2011; Yıldırım, 2001) tarafından yapılan araştırmaların bulgularıyla örtüşmektedir. Bazı araştırmalarda ise sonuçlar farklı çıkmıştır. Aksu, Fırat ve Şahin (2003) ve Maya'nın (2017) yaptığı araştırmalarda, öğretmenlere göre okul müdürlerinin kültürel liderlik davranışları düzeyinin "orta" olduğu bulunmuştur. Tahaoğlu ve Gedikoğlu (2009) tarafindan yapılan araştırmada, öğretmenlere göre müdürlerinin kültürel liderlik rolleri "Kararsızım" düzeyinde olduğu sonucuna ulaşılmıştır. İbicioğlu (1999) ve Gedikoğlu, Şahin ve Büyükelbaşı (2004) yaptığı araştırmalarda, öğretmenlere göre okul yöneticilerinin kültürel liderlik davranışlarının "yetersiz" olduğu bulunmuştur. Atay'ın (2001) çalışmasında ise öğretmenlerin 
görüşlerine göre, ilköğretim okulu yöneticilerinin kültürel liderlik davranışlarının düzeyinin "az" olduğu sonucuna ulaşılmıştır. Bu araştırmada ise okul yöneticilerin kültürel liderlik davranışları düzeyinin olumlu ve yüksek çıkması, okullardaki etkili iletişimin olması, sosyal ve kültürel etkinliklerin düzenlenmesi, başarılı ekip çalışmalarının yapılması, amaçların açıkça ifade edilmesi ve güçlü bir okul kültürünün olmasından dolayı sonucun bu yönde çıkmasını sağlamış olabilir.

Araştırmanın ikinci alt amacının sonucuna göre öğretmenlerin ilkokul yöneticilerinin kültürel liderlik davranışları düzeylerine ilişkin algıları cinsiyetlerine göre anlamlı olarak fark olmadığı bulunmuştur. Buna göre kadın ve erkek öğretmenlerin kültürel liderlik algılarının benzer olduğu söylenebilir. Araştırmanın bulgularıyla, (Aksu vd., 2003; Çek, 2011; Değirmenci, 2006; Derin, 2003; Maya, 2017; Tahaoğlu ve Gedikoğlu, 2009; Tuna, 2014; Yıldırım, 2001) tarafindan yapılan araştırmaların bulgularıyla örtüşmektedir. Bazı araştırmalarda ise sonuçlar farklı çıkmıştır. Hiçyılmaz (2013) ve Ay’ın (2014) yaptı̆̆ 1 araştırmalarda ise öğretmenlerin okul yöneticilerinin kültürel liderlik davranışları düzeylerine ilişkin algıları cinsiyetlerine göre anlamlı olarak fark olduğunu belirlemişler, erkek öğretmenlerin kültürel liderlik algısının kadın öğretmenlerden daha yüksek olduğunu bulmuşlardır. Sonuçların farklı olması araştırmaların yapıldığı yıl, bölge, evren ve örneklemin farklı olmasından kaynaklandığı söylenebilir.

Araştırmada öğretmenlerin ilkokul yöneticilerinin kültürel liderlik davranışları düzeylerine ilişkin algıları mesleki kıdemlerine göre anlamlı fark olmadığı tespit edilmiştir. Buna göre öğretmenlerin mesleki kıdemleri farklı olsa da kültürel liderlik algılarının benzer olduğu söylenebilir. Araştırmanın bulgularıyla, (Aksu vd., 2003; Ay, 2014; Değirmenci, 2006; Derin, 2003; Tahaoğlu ve Gedikoğlu, 2009; Tuna, 2014) tarafından yapılan araştırmaların bulgularıyla örtüşmektedir. Bazı araştırmalarda ise sonuçlar farklı çıkmıştır. Hiçyılmaz (2013), Maya (2017) ve Yıldırım (2001) yaptıkları araştırmalarda öğretmenlerin okul yöneticilerinin kültürel liderlik davranışları düzeylerine ilişkin görüşleri kıdemlerine göre anlamlı farklılık olduğunu belirlemişler, mesleki kıdemi yüksek olan öğretmenlerin kültürel liderlik algısının mesleki kıdemi düşük olan öğretmenlerden daha yüksek olduğunu tespit etmişlerdir.

Araştırmada öğretmenlerin ilkokul yöneticilerinin kültürel liderlik davranışları düzeylerine ilişkin algıları branşlarına göre anlamlı olarak fark olmadığı belirlenmiştir. Buna göre sınıf ve branş öğretmenlerin kültürel liderlik algılarının benzerlik gösterdiği söylenebilir. Araştırmanın bulgularıyla, (Çek, 2011; Değirmenci, 2006; Derin, 2003; Maya, 2017; Tahaoğlu ve Gedikoğlu, 2009; Tuna, 2014; Yıldırım, 2001) tarafından yapılan araştırmaların bulgularıyla örtüşmektedir. Aksu vd., (2003) yaptığı araştırmada ise öğretmenlerin okul müdürlerinin kültürel liderlik davranışları düzeylerine ilişkin algıları arasında branşa göre anlamlı olarak fark olduğu belirlemiş, branş öğretmenlerin kültürel liderlik algısının sınıf öğretmenlerinden daha yüksek olduğunu bulmuşlardır. Sonuçların farklı olması araştırmaların evren ve örneklemin farklı olmasından kaynaklandığı söylenebilir.

Araştırmada öğretmenlerin ilkokul yöneticilerinin kültürel liderlik davranışları düzeylerine ilişkin algıları öğrenim durumlarına göre anlamlı olarak farklılaşmadığı tespit edilmiştir. Buna göre lisans ve lisansüstü mezunu öğretmenlerin kültürel liderlik algılarının benzerlik gösterdiği söylenebilir. Araştırmanın bulgularıla, (Aksu vd., 2003; Çek, 2011; Değirmenci, 2006; Tuna, 2014) tarafından yapılan araştırmaların bulgularıyla örtüşmektedir. Ay'ın (2014) yaptığı araştırmada ise öğretmenlerin okul yöneticilerinin kültürel liderlik düzeylerine ilişkin algıları öğrenim durumlarına göre anlamlı olarak farklılık olduğu belirlemiş, önlisans+lisans mezunu öğretmenlerin kültürel liderlik algısının lisansüstü mezunu öğretmenlerden daha yüksek olduğunu bulmuştur.

Araştırmanın üçüncü alt amacın sonucuna göre öğretmenlerin ilkokullarındaki örgütsel imajına ilişkin algı düzeyleri "Oldukça Katıllyorum" olduğu belirlenmiştir. Bu sonuca göre ilkokul öğretmenlerinin örgütsel imaj algıları yüksektir. Araştırmanın bulgularıyla (Akbulut, 2015; Akman, 2017; Akman, 2019; Demiröz, 2014; Kılınçaslan, 2011; Selçuk, 2018; Şimşek, 2018) tarafindan yapılan araştırmaların bulgularıyla örtüşmektedir. Bazı araştırmalarda ise sonuçlar farklı çıkmıştır, (Gençay, 2014; Şanlı ve Arabac1, 2016; Uğurlu ve Ceylan, 2013) tarafından yapılan araştırmalarda, öğretmenlerin örgütsel imaj algılarının orta düzeyde olduğu sonucuna ulaşılmıştır. Bu araştırmada 
öğretmenlerin örgütsel imajlarının olumlu ve yüksek olmasının, okullarının merkez ilçelerde olması, çevrelerinin sosyo ekonomik durumlarının iyi olması, okul yöneticilerin görev ve sorumluluklarını başarıyla yerine getirmeleri, okul yöneticilerinin liderlik davranışlarını sergilemeleri, okulun amaçlarının iyi belirlenmesi araştırmanın sonucunun bu yönde çıkmasını sağlamış olabilir.

Araştırmanın dördüncü alt amacının sonucuna göre öğretmenlerin ilkokullarındaki örgütsel imaj düzeylerine ilişkin algıları cinsiyetlerine göre anlamlı olarak farklılaşmadığı bulunmuştur. Buna göre kadın ve erkek öğretmenlerin örgütsel imaj algılarının benzer olduğu söylenebilir. Araştırmanın bulgularıyla, (Akman, 2019; Demiröz, 2014; Selçuk, 2018; Uğurlu ve Ceylan, 2013) tarafindan yapılan araştırmaların bulgularıyla örtüşmektedir. Bazı araştırmalarda ise sonuçlar farklı çıkmıştır, (Akbulut, 2015; Akman, 2017; Duman, 2012; Erdoğdu, Umurkan ve Kuru, 2013; Gençay, 2014; Kılınçaslan, 2011; Kurşun, 2011; Şanlı ve Arabac1, 2016; Şimşek, 2018; Zengin, 2019) tarafindan yapılan araştırmalarda öğretmenlerin okullarındaki örgütsel imaj düzeylerine ilişkin algıları cinsiyetlerine göre anlamlı olarak farklılık olduğunu belirlemişlerdir. Sonuçların farklı olması araştırmaların yapıldığı yıl, bölge, evren ve örneklemin farklı olmasından kaynaklandığı söylenebilir.

Araştırmada öğretmenlerin ilkokullarındaki örgütsel imaj düzeylerine ilişkin algıları mesleki kıdemlerine göre anlamlı farklılaşmadığı belirlenmiştir. Buna göre öğretmenlerin mesleki kıdemleri farklı olsa da örgütsel imaj algılarının benzer olduğu söylenebilir. Araştırmanın bulgularıyla, (Duman, 2012; Selçuk, 2018; Şahin, 2014; Zengin, 2019) tarafından yapılan araştırmaların bulgularıyla örtüşmektedir. Bazı araştırmalarda ise sonuçlar farklı çıkmıştır, (Akbulut, 2015; Akman, 2017; Akman, 2019; Demiröz, 2014; Gençay, 2014; Kılınçaslan, 2011; Şanlı ve Arabac1, 2016; Şimşek, 2018) tarafından yapılan araştırmalarda öğretmenlerin okullarındaki örgütsel imaj düzeylerine ilişkin algıları mesleki kıdemlerine göre anlamlı olarak farklılık olduğunu belirlemişlerdir.

Araştırmada öğretmenlerin ilkokullarındaki örgütsel imaj düzeylerine ilişkin algıları branşlarına göre anlamlı olarak farklılaşmadığı bulunmuştur. Buna göre sınıf ve branş ögretmenlerin örgütsel imaj algılarının benzerlik gösterdiği söylenebilir. Araştırmanın bulgularıyla, (Kurşun, 2011; Şanlı ve Arabacı, 2016; Uğurlu ve Ceylan, 2013) tarafından yapılan araştırmaların bulgularıyla örtüşmektedir. Bazı araştırmalarda ise sonuçlar farklı çıkmıştır, (Akbulut, 2015; Erdoğdu vd., 2013; Şimşek, 2018) tarafından yapılan araştırmalarda öğretmenlerin okullarındaki örgütsel imaj düzeylerine ilişkin algıları branşlarına göre anlamlı olarak farklılık olduğunu belirlemişlerdir. Sonuçların farklı olması araştırmaların evren ve örneklemin farklı olmasından kaynaklandığı söylenebilir.

Araştırmada öğretmenlerin ilkokullarındaki örgütsel imaj düzeylerine ilişkin algıları öğrenim durumlarına göre anlamlı olarak fark olmadığı tespit edilmiştir. Buna göre öğretmenlerin öğrenim durumları ilkokullarındaki örgütsel imaj düzeylerine ilişkin öğretmen algılarını etkileyen bir faktör olmadığı söylenebilir. Lisans ve lisansüstü mezunu öğretmenlerin örgütsel imaj algılarının benzer olduğu ifade edilebilir. Araştırmanın bulgularıyla, (Demiröz, 2014; Gençay, 2014; Kurşun, 2011; Zengin, 2019) tarafından yapılan araştırmaların bulgularıyla örtüşmektedir. Bazı araştırmalarda ise sonuçlar farklı çıkmıştır, (Akman, 2017; Akman, 2019; Duman, 2012; Erdoğdu vd., 2013; Kılınçaslan, 2011; Selçuk, 2018; Şimşek, 2018) tarafından yapılan araştırmalarda öğretmenlerin okullarındaki örgütsel imaj düzeylerine ilişkin algıları öğrenim durumlarına göre anlamlı olarak farklılık olduğunu belirlemişlerdir.

Araştırmanın beşinci alt amacın sonucunda ilkokul yöneticilerinin kültürel liderlik davranışlarıyla öğretmenlerin örgütsel imajı arasında istatistiksel olarak orta düzeyde pozitif yönlü anlamlı bir ilişkinin olduğu bulunmuştur. Bu bulguya göre okul yöneticilerin kültürel liderlik davranışları artıkça öğretmenlerin örgütsel imaj algılarıda yükseleceği söylenebilir. Kurşun'un (2011) araştırmasının sonucunda, ilköğretim okulu öğretmenlerine göre ilköğretim okulu yöneticilerinin etik liderlik özelliklerinin kurumsal imajı olumlu yönde etkilediği bulunmuştur. Pawlas’a (1999) göre okul imajının oluşmasında okul yöneticilerinin liderlik davranışlarına bağlı olduğunu belirtmiştir (Akt. Bahçeci, 2009). Erdoğdu vd., (2013) tarafından yapılan araştırmada ise öğretmenlere göre ilköğretim okulu yöneticilerinin etik liderlik rolleriyle öğretmenlerin kurum imajları arasında istatistiksel olarak yüksek ve anlamlı ilişkinin olduğu bulunmuştur. Gençay’ın (2014) yaptığı araştırmanın sonucunda, 
öğretmenlerin görüşlerine göre okul yöneticilerinin dönüşümcü liderlik stilleriyle okul imajları arasında istatistiksel olarak orta düzeyde bir ilişkinin olduğu belirlenmiştir. Zengin'in (2019) yaptığ1 araştırmanın sonucunda ise öğretmenlere göre ortaöğretim okulu müdürlerinin dönüşümcü liderlik özellikleriyle örgütsel imajları arasında pozitif yönlü anlamlı ilişkinin olduğu bulunmuştur. Örgütün devamlılığı ve başarısı için olumlu bir imaj gereklidir. Okul yöneticileri kültürel liderlik davranışlarını en iyi şekilde yerine getirerek öğretmenlerin örgütsel imajının olumlu yönde artmasını sağlayabilir. Bu sayede öğretmenlerin motivasyonları yükselebilir, performansları ve okula bağlılıkları artabilir. Sonuçta okul, belirlenen hedeflerini kolaylıkla gerçekleştirecektir.

Araştırmadan elde edilen bulgulara göre şu önerilerde bulunulmuştur; Okullarda kültürel liderlikle ilgili hem okul müdürlerine hem de öğretmenlere uygulamalı dersler, kurslar, seminerler ve hizmetiçi eğitimler verilebilir. Örgütsel imaj örgütlerin devamlılı̆̆ 1 ve başarısı için gereklidir. Bundan dolayı örgütsel imajı etki eden faktörler belirlenebilir. Bu araştırmada nicel araştırma yöntemi kullanılmış olup, kültürel liderlik ve örgütsel imajı daha detaylı incelemek için nitel araştırma yöntemleri veya karma yöntemler kullanılarak araştırılabilir. Kültürel liderlik ve örgütsel imaj konularında meta analiz çalışmaları yapılabilir.

\section{Yazarların Katkı Oranı}

Çalışma tek yazarlı olduğu için yazarın katkı oranı \%100'dür.

\section{Çıkar Çatışması}

Bu çalışmada çıkar çatışması oluşturacak bir husus yoktur.

\section{Kaynaklar}

Ak, M. (2017). Örgütsel bağl1lığın örgütsel etkililik üzerinde etkisi: bir değerlendirme. Anadolu Kültürel Araştırmalar Dergisi, 1(3), 27-42.

Akbulut, B. (2015). Ortä̈ğretim kurumlarında görev yapan öğretmenlerin örgütsel imaj algıları ile iş doyumu düzeyleri arasındaki iliş̧ki. Doktora Tezi, Hacettepe Üniversitesi, Eğitim Bilimleri Enstitüsü, Ankara.

Akman, A. (2019). Ortaokulların benimsedikleri örgütsel değerler ile ögretmenlerin okul imajına ilişkin algıları. Yüksek Lisans Tezi, Bolu Abant İzzet Baysal Üniversitesi, Eğitim Bilimleri Enstitüsü, Bolu.

Akman, Y. (2017). Örgütsel çekicilik, örgütsel imaj ve örgütsel sadakat arasındaki ilişkilerin ögretmen görüşlerine göre incelenmesi. Doktora Tezi, Hacettepe Üniversitesi, Eğitim Bilimleri Enstitüsü, Ankara.

Aksu, A., Fırat, N.Ş. ve Şahin, İ. (2003). İlköğretim okulu müdürlerinin kültürel liderlik davranışları. Kuram ve Uygulamada Ĕ̈itim Yönetimi, 9(4), 490-507.

Atay, K. (2001). Öğretmen yönetici ve denetmenlerin bakış açısından okul kültürü ve öğretmenlerin verimliliğine etkisi. Kuram ve Uygulamada Egitim Yönetimi, 7(2), 179-194.

Ay, M. H. (2014). Okul yöneticilerinin kültürel liderlik düzeyleri ile öğretmenlerin örgütsel güven düzeyleri arasındaki iliş̧ki. Yüksek Lisans Tezi, Uşak Üniversitesi, Sosyal Bilimler Enstitüsü, Uşak.

Bahçeci, M. (2009). Velilerin okul imajına ilişkin görüşlerinin incelenmesi. Yüksek Lisans Tezi, Marmara Üniversitesi, Eğitim Bilimleri Enstitüsü, İstanbul. 
Baker, G. and Associates (1992). Cultural leadership: Inside America's community colleges. Washington DC: American Association of Community and Junior Colleges.

Bolat, İ. O. (2006). Konaklama işletmelerinde işgörenlerden yansıyan kurumsal imajın analizi ve bir uygulama. Doktora Tezi, Balıkesir Üniversitesi, Sosyal Bilimler Enstitüsü, Balıkesir.

Buluç, B. (2013). Okul kültürü ve iklimi. S. Özdemir (Ed.), Eğitim Yönetiminde Kuram ve Uygulama içinde (ss.101-130). Ankara: PegemA.

Bursalığlu, Z. (2005). Okul yönetimde yeni yapı ve davranış (13. Baskı). Ankara: Pegem A Yayıncilik.

Büyüköztürk, Ş. (2008). Sosyal bilimler için veri analizi el kitabı (9. bask1). Ankara: Pegem Akademi.

Çek, F. (2011). Bă̆ımsız anaokulu ve ilköğretim okulu müdürlerinin kültürel liderlik davranışları ile okul öncesi ögretmenlerinin iş doyumu arasındaki ilişki. Yüksek Lisans Tezi, Dokuz Eylül Üniversitesi, Eğitim Bilimleri Enstitüsü, İzmir.

Çelikten, M. (2003). Okul kültürünün şekillendirilmesinde müdürün rolleri. Türk Eğitim Bilimleri Dergisi, 1(4), 453-462.

Değirmenci, S. (2006). Lise yöneticilerinin kültürel liderlik rollerinin öğretmenlerin iş doyumuna etkisi. Yüksek Lisans Tezi, Abant İzzet Baysal Üniversitesi, Sosyal Bilimler Enstitüsü, Bolu.

Demiröz, S. (2014). Öğretmenlerin örgütsel vatandaşlık davranışları, örgütsel imaj algıları ve ögrrenci başarıları arasındaki ilişki. Doktora Tezi, Hacettepe Üniversitesi, Eğitim Bilimleri Enstitüsü, Ankara.

Derin, Ö. (2003). Dershane yöneticilerinin kültürel liderlik rollerinin öğretmenlerin iş doyumuna etkileri. Yüksek Lisans Tezi, Fırat Üniversitesi, Sosyal Bilimler Enstitüsü, Elazığ.

Dincer M. K. (1998). Kişisel imaj. İstanbul: Alfa Yayınları.

Dutton, J. E. and Dukerich, J. M. (1991). Keeping an eye on the mirror: image and identity in organizational adaptation, Academy Of Management Journal, 34 (3), 517-554.

Duman, Ş. (2012). İlköğretim okullarında kurumsal imaj ve imaj yönetimi. Yüksek Lisans Tezi, Fırat Üniversitesi, Eğitim Bilimleri Enstitüsü, Elazı ̆̆.

Erdoğan, B. Z., Develioğlu K., Gönüllüoğlu S. ve Özkaya, H. (2006). Kurumsal imajın şirketin farklı paydaşları tarafindan algılanışı üzerine bir araştırma. Dumlupınar Üniversitesi SBE Dergisi, (15), 55-76.

Erdoğdu, M. Y., Umurkan, F. ve Kuru, F. (2013). Okul yöneticilerinin etik liderlik rolleri ile kurum imaj1 arasındaki ilişki. İstanbul Sabahattin Zaim Üniversitesi Sosyal Bilimler Dergisi, 2(3), $37-54$.

Frandsen, S. (2017). Organizational image. C.R. Scott and L. Lewis (Eds.). The international encyclopedia of organizational communication, 4 volume set in (pp.1795-1804). Chichester, UK: John Wiley and Sons, Inc.

Gedikoğlu, T., Şahin, S. ve Büyükelbaşı, Ö. (2004). İlköğretim okulu yöneticilerinin kültürel liderlik davranışlarına ilişkin yönetici ve öğretmen algıları. M. Ü. Atatürk Ĕgitim Fakültesi Eğitim Bilimleri Dergisi, 19(19), 73-84. 
Gençay, A. (2014). Öğretmenlerin görüşlerine göre okul yöneticilerinin liderlik stilleri ve okul imajl. Yüksek Lisans Tezi, Yıldız Teknik Üniversitesi, Sosyal Bilimler Enstitüsü, İstanbul.

Geylani, A. (2013). Okul yönetiminde kültürel liderlik yaklaşımı ve toplumsal boyutu. Karatekin Edebiyat Fakültesi Dergisi, 1(1), 1-23.

Gürsel, M. (2003). Örgütte iletişim. H. Izgar (Ed)., Endüstri ve örgüt psikolojisi içinde (ss. 39-56). Konya: Eğitim Kitabevi Yayınları.

Hiçy1lmaz, Y. (2013). İlkögrretim okul müdürlerinin kültürel liderlik davranışları. Yüksek Lisans Tezi, Dokuz Eylül Üniversitesi, Eğitim Bilimleri Enstitüsü, İzmir.

Hoy, W. K. and Miskel, C. G. (2015). Eğitim yönetimi: Teori, araştırma ve uygulama (S. Turan, Çev. Ed.). Ankara: Nobel Akademik.

İbicioğlu, C. (1999). İlköğretim okulu yöneticilerinin kültürel liderlik davranışları. Yüksek Lisans Tezi, İnönü Üniversitesi, Sosyal Bilimler Enstitüsü, Malatya.

Karasar, N. (2008). Bilimsel araştırma yöntemi (18. Basım). Ankara: Nobel Yayın Dağıtım.

Kılıçaslan, H. (2011). İlköğretim okullarının kurumsal imajına yönelik yönetici ve öğretmen algıları: Bolu ili merkez ilçesi örneği. Yüksek Lisans Tezi, Abant İzzet Baysal Üniversitesi, Sosyal Bilimler Enstitüsü, Bolu.

Köksal, O. (2011). Bir kültürel liderlik paradoksu: Paternalizm. Mustafa Kemal Üniversitesi Sosyal Bilimler Enstitüsü Dergisi, 8(15), 101-122.

Kurşun, A. T. (2011). Okulların kurumsal imajının okul yöneticilerinin etik liderlik özellikleri ve bazı değişkenler açısından incelenmesi. Yüksek Lisans Tezi, Selçuk üniversitesi, Eğitim Bilimleri Enstitüsü, Konya.

Lane, B. (1992). Cultural leaders in effective schools: The builders and brokers of excellence, NASSP Bulletin, 76(541), 85-96.

Lievens, F. (2017). Organizational image/reputation. S. Rogelberg and C.L. Reeve (Eds.) The the encyclopedia of industrial and organizational psychology in (pp. 1116-1118), 2nd edition. Thousands Oaks, CA: Sage.

Lunenburg, F. C. and Ornstein, A. C. (2013). Ĕgitim yönetimi (G. Arastaman, Çev. Ed.). Ankara: Nobel.

Maya, İ. (2017). İlkokul öğretmenlerinin algılarına göre okul müdürlerinin kültürel liderlik davranışlarını gösterme düzeyleri. Yönetim Bilimleri Dergisi, 15(29), 107-126.

Okay, A. (2000). Kurum kimliği (2.Baskı). Ankara: MediaCat Kitapları.

Özdemir, S. (2012). İlköğretim okullarında okul kültürü ile örgütsel sağlık arasındaki ilişki. Kuram ve Uygulamada Eğitim Yönetimi [Educational Administration: Theory and Practice], 18(4), 599620.

Peltekoğlu, F. B. (1997). Kurumsal iletişim sürecinde imajın yeri. İstanbul Üniversitesi İletişim Fakültesi Dergisi, (4), 125-145.

Pérez, J.P. and Torres, E.M. (2017). Evaluation of the organizational image of a university in a higher education institution. Contaduría y Administración, 62(1), 123-140. https://doi.org/10.1016/j.cya.2016.01.007. 
Selçuk, Ş. (2018). Özel ortaöğretim kurumlarında yöneticilerin inovasyon yeterlilikleri ile örgütsel imaj algısı ilişkisi. Yüksek Lisans Tezi, Hacettepe Üniversitesi, Eğitim Bilimleri Enstitüsü, Ankara.

Schein, E. H. (1990). Organizational culture. American Psychologist, 45 (2), 109-119.

Şahin, E. (2014). Ortaöğretim kurumlarında örgütsel kimlik, örgütsel imaj, örgütsel özdeşleşme ve örgütsel adalet (Bursa örneği). Doktora Tezi, Ege Üniversitesi, Sosyal Bilimler Enstitüsü, İzmir.

Şanlı, Ö. ve Arabacı, İ. B. (2016). Liselerde çalışan öğretmenlerin örgütsel kimlik ve örgütsel imaj algılarının örgütsel bağlılıklarına etkisi. Education Sciences (NWSAES), 11(3), 126-152. http://dx.doi.org/10.12739/NWSA.2016.11.3.1C0658.

Şimşek, M. (2018). Öğretmenlerin örgütsel imaj algıları ile psikolojik iyi olma düzeyleri arasındaki ilişki. Yüksek Lisans Tezi, Kahramanmaraş Sütçü İmam Üniversitesi, Sosyal Bilimler Enstitüsü, Kahramanmaraş.

Şişman, M. (1995). Örgüt kavramının kültürel açıdan çözümlenmesi ve eğitim örgütleri. Eğitim Yönetimi, 1(1), 79-94.

Uygur, M. ve Yıldırım, A. (2011). İlköğretim okulu yöneticilerinin kültürel liderlik rolleri ile öğretmenlerin örgütsel bağl1lı̆̆1 arasındaki ilişki. Gazi Üniversitesi Endüstriyel Sanatlar Eğitim Fakültesi Dergisi, (27), 72-81.

Tahaoğlu, F. ve Gedikoğlu, T. (2009). İlköğretim okulu müdürlerinin liderlik rolleri. Kuram ve Uygulamada Ĕ̈itim Yönetimi Dergisi, 15(58), 274-298.

Terzi, A. R. (2000). Örgüt kültürü. Ankara: Nobel Yayınları.

Tuna, M. R. (2014). Ortaokul müdürlerinin kültürel liderlik rolünün öğrenen okul düzeyine etkisi (İstanbul-Beykoz örneği). Yüksek Lisans Tezi, İstanbul Aydın Üniversitesi, Sosyal Bilimler Enstitüsü, İstanbul.

Uğurlu, C. T. ve Ceylan, N. (2013). Öğretmenlerin, okullarına ilişkin örgütsel imaj algılarının bazı değişkenler açısından incelenmesi. Ondokuz Mayls Üniversitesi Eğitim Fakültesi Dergisi, 32(2), 301-322.

Vigoda-Gadot, E., Vinarski-Peretz, H., \& Ben-Zion, E. (2003). Politics and image in the organizational landscape: An empirical examination among public sector employees. Journal of Managerial Psychology, 18(8), $764-787$.

Yıldırım, B. (2001). Okul yöneticilerinin kültürel liderlik rollerinin öğretmenlerin iş doyumuna ve meslek ahlakına etkisi. Doktora Tezi, Fırat Üniversitesi, Sosyal Bilimler Enstitüsü, Elazığ.

Zengin, M. (2001). Ortaöğretimde okul müdürlerinin dönüşümcü liderlik özellikleri ile okul güvenliği ve örgütsel imaj arasındaki ilişki. Doktora Tezi, Atatürk Üniversitesi, Eğitim Bilimleri Enstitüsü, Erzurum. 


\section{Extended Abstract}

\section{Introduction}

The concept of organizational culture has started to be used as a popular concept since the 1980s. Not only organization and management theory has become the focus of attention of scientists in other social sciences (Şişman, 1995). In this context, the concept of organizational culture has influenced leadership research, especially cultural leadership. Cultural leadership can be defined as an alternative perspective of school leadership that participates in the evaluation, creation and mediation of core values and norms leading to school effectiveness (Lane, 1992). The behavior of the cultural leader is to keep the organizational culture alive. He is the cultural leader who works for the formation of cultural values in organizations, knows the values, explains them and ensures the integration of employees with these values. Therefore, cultural leaders seek to ensure that employees learn, internalize and use the organization's ideas, values, norms, history, heroes, languages and ceremonies (Maya, 2017).

In the twentieth century, organizational image became the main subject of managers in all sectors, professions and regions across the world (Vigoda Gadot, Vinarski-Peretz and Ben-Zion, 2003). According to Dutton and Dukerich (1991), organizational image is the thoughts of all stakeholders of the organization about the organization. According to Livens (2017), organizational image is people's knowledge and beliefs about Organization. The organizational image perceived by an organization's audience and employees directly influences the effective performance of organizations (Pérez and Torres, 2017). In this context, a strong and positive organizational image is required for the continuity and success of the organization. A strong organizational image adds value to organizations in terms of feeling, enables organizations to be noticed and trusted, and allows them to get ahead of their competitors (Erdoğan, Develioğlu, Gönderoğlu and Özkan, 2006). A positive school image increases the motivation of employees in the school, enables them to use their performances more effectively and more efficiently, cooperate, improve job satisfaction and increase loyalty (Duman, 2012). The aim of this research is to determine the relationship between the cultural leadership behaviors of primary school principals and the organizational image of teachers according to the perceptions of teachers.

\section{Method}

Quantitative research method was used in the study. The relational screening model has been used when investigating the relationship between cultural leadership and organizational image. In this model, the existence and degree of variation between two or more variables is attempted to be determined (Karasar, 2008). The universe of research covers teachers working in public schools in Konya province in the 2018-2019 academic year. The sample of the research is 380 teachers selected from 18 primary schools by simple random sampling method. In the collection of research data, "Cultural Leadership Scale" and "Organizational Image Scale" were used. SPSS package program was used in the analysis of the data obtained in the research. The study used arithmetic average, standard deviation, Mann Whitney U-test, Kruskal Wallis H-test and Spearman rho correlation analysis in analyzing data.

\section{Findings}

It was determined that the level of cultural leadership behaviors of primary school principals was "Agree" according to the teachers involved in the study. Teachers' perception levels regarding their organizational image in primary schools were found to be "quite agree". It was found that there was a statistically moderate positive correlation between the cultural leadership behavior of primary school principals and the organizational image of teachers. 


\section{Conclusions, Discussion and Recommendations}

As a result of the first sub-objective of the study, the cultural leadership behaviour of primary school principals has come close to high. According to this result, primary school principals successfully exhibit cultural leadership behaviors. The findings of the study coincide with the findings of the research conducted by (Ay, 2014; Çek, 2011; Değirmenci, 2006; Derin, 2003; Hiçy1lmaz, 2013; Uygur and Yildırım, 2011; Yildırım, 2001). In this study, the positive and high level of cultural leadership behavior of school principals, effective communication in schools, organization of social and cultural activities, successful teamwork, clear expression of goals and a strong school culture may have led to the result in this direction.

According to the conclusion of the third sub-objective of the study, primary school teachers' perceptions of organizational image are high. The findings of the study (Akbulut, 2015; Akman, 2017; Akman, 2019; Demiröz, 2014; Kılınçaslan, 2011; Selçuk, 2018; Şimşek, 2018) coincide with the findings of the research conducted by. In this research, the positive and high organizational image of the teachers, schools in the central districts, the environment is good socio-economic situation, school principals to fulfill their duties and responsibilities successfully, school principals to exhibit the leadership behavior of the school may be the result of this research.

As a result of the fifth sub-objective of the study, it was found that there was a statistically moderate positive correlation between the cultural leadership behavior of primary school principals and the organizational image of teachers. According to this finding, as the cultural leadership behaviors of school principals increase, teachers' perceptions of organizational image will increase. As a result of Kurşun's (2011) research, it was found that the ethical leadership characteristics of primary school administrators, according to primary school teachers, positively affect the corporate image. Pawlas (1999) stated that the formation of school image depends on the leadership behavior of school administrators (as cited in Bahçeci, 2009). A positive image is needed for the continuity and success of the organization. Principals can ensure that teachers ' organizational image is positively enhanced by performing cultural leadership behaviors in the best way possible. This increases the motivation of the teachers, increases their performance and loyalty to the school. As a result, the school will easily accomplish its set goals.

According to the findings of the research, the following suggestions were made; Practical courses, courses, seminars and in-service trainings can be given to school principals and teachers on cultural leadership in schools. Organizational image is essential for the continuity and success of organizations. Therefore, factors affecting organizational image can be determined. The quantitative research method has been used in this research and can be investigated using qualitative research methods or mixed methods to further examine cultural leadership and organizational image. Metaanalysis studies can be done on cultural leadership and organizational image issues. 